\title{
The Manifestation of Grotesque Romance through Deviant Sexuality in Tunku Halim's Dark Demon Rising
}

\author{
Nur Fatin Syuhada Ahmad Jafni \\ Faculty of Modern Languages and Communication, University Putra Malaysia \\ Wan Roselezam Wan Yahya \\ Faculty of Modern Languages and Communication, University Putra Malaysia
}

Received: 26-04-2015

doi:10.7575/aiac.ijclts.v.3n.3p.20
Accepted: 19-06- 2015

Published: 31-07- 2015

\begin{abstract}
Dark Demon Rising (1997) is the debut novel written by an established Malaysian horror stories author, Tunku Halim. Dark Demon Rising narrates the journey of the protagonist, Shazral Abbas, and his encounter with his dark childhood and dangerous future. This paper aims to examine the relationship between Shazral and Minah, specifically the representation of the grotesque through deviant sexuality. To illustrate and depict grotesque romance, a textual analysis is carried out and close reference to the definition of grotesque is applied as the framework of the study. The term 'grotesque romance' is coined throughout this study to show the type of relationship entered into by the protagonist and his lover. There are three components of grotesque that are embodied in the notion of grotesque romance in the novel; 'demonic fantasy', 'the excessive and the unreal' and 'the horrifying and the attractive'. Our findings illustrate that these three components of grotesque are manifested through the action of deviant sexuality and represented in two ways; 1) pre-marital sex prohibited by religion and culture, and 2) the relationship between two different entities - human and demon.
\end{abstract}

Keywords: Grotesque, Deviant Sexuality, Romance, Horror Stories

\section{Introduction}

The subject of love and romance is one of the most common and highly celebrated themes in literature, from the tragic love stories of Shakespeare's Romeo and Juliet, gothic romance in Bronte's Wuthering Heights and chivalric romance in de Cervantes' Don Quixote to William Butler Yeats' Leda and the Swan and Robert Browning's My Last Duchess. The theme of love can also be traced back to the mediaeval age. The theme of courtly love, for example, can be defined as the act of worshipping and pining after women on a different level, i.e. married women or women of higher status, and such differences make the consummation of love impossible (Halimah Mohamed Ali, 2013, p.11). Speaking of the consummation of love and romance, the subject of this paper centres on the protagonist of the novel of Dark Demon Rising (1997), written by an established Malaysian author of horror stories, Tunku Halim.

The story revolves around the protagonist, Shazral Abbas, and his journey from being a successful lawyer in the city to a village bomoh (shaman). In the bustle of the city, Shazral meets a young beautiful girl,called Minah, in Ziggy's Zag, a fancy night club. Their relationship eventually evolves from being friends into lovers. Shazral is very much smitten by the beauty, vibrant laughter and positive nature of Minah. In Minah, Shazral believes that he has found his one true love. But little does he know that Minah approached him with ulterior motives, to destroy his good spirit, hantu pusaka, the spirit Shazral inherited from his father. A malicious spirit has been following and haunting Shazral ever since he asked his uncle to put a spell on his toy boat, years before. Minah appeared and materialized as a beautiful and seductive woman, when in fact she is a different entity from Shazral. As the title of the novel suggests, Minah is a dark demon, the monstrous spirit of hantu jahat.

The romance and love portrayed by Shazral and Minah are strange, to the point of being grotesque. In a typical heterosexual romance, one expects to find elements such as "courtship, manners, conflict and finally marriage" (Zirange, 2013, p. 91). The unmarried couple have broken the moral and religious code of conduct, as they have committed the act of deviant sexuality. Shazral is a Malay man, who has lived in a village since he was born. The village is orthodox Malay whose culture uholds Malay moral conduct and belief in Islamic teaching. In accordance with Islamic teaching and the Malay moral conduct, Shazral's demeanour in his relationship with Minah can be seen as denyinghis faith. The romance between the two is therefore deemed grotesque, urging us to label such a relationship as a 'grotesque romance'. The notion of grotesque romance is manifested through the deviant sexuality performed by Shazral and Minah. It is sexually deviant as the relationship involves 1) premarital sex, and 2) communion between human and nonhuman entities. 
Apart from the journey of Shazral as the new master of the family's inheritance (the good spirit hantu pusaka), the novel also revolves around Shazral's love affair. The story narrates Shazral's relationship with a beautiful city girl, Minah and his first love, Roslyah. Although there are two different love stories in the novel, we will only focus on the relationship between Shazral and Minah. As the scope of the study depends specifically on Shazral and Minah, this study seeks to examine the kind of relationship exhibited by these two characters. To be precise, we will examine the representation of 'grotesque romance' and how the notion is depicted by the actions of deviant sexuality demonstrated by Shazral and Minah.

Basing on textual analysis as our research methodology, we will first review the definitions of grotesque and deviant sexuality, and how the latter concept is set within the milieu of the grotesque concept. Subsequently, we will illustrate the types of sexual deviance displayed by the relationship between the two characters. To achieve the aim of this study, a lengthy discussion on the concept of grotesque as depicted through the acts of deviant sexuality in accordance with the textual evidence will be carried out inan analysis section. We divide the analysis into three parts that parallel the three components of grotesque we proposed as factors contributing to a 'grotesque romance'. The components that serve as the framework of this study are 'demonic fantasy', 'the excessive and the unreal' and 'the horrifying and the attractive'.

\section{The Grotesque And Deviant Sexuality}

The word 'deviant' is synonymous with words like eccentric, abnormal, freakish, uncommon, bizarre and abhorrent. The Oxford Dictionary defines deviant as "departing from usual or accepted standards, especially in social or sexual behaviour" (2014). The word sexuality is defined as "the capacity for sexual feelings", i.e. sexual preferences or sexual activity (Oxford Dictionary, 2014). On the notion of deviant sexuality, the Blackwell Encyclopedia of Sociology Online explains that "this concept refers to behaviours that involve individuals seeking erotic gratification through means that are considered odd, different, or unacceptable to either most or influential persons in one's community" (2007). In light to this study, deviant sexuality is the unusual sexual relationship depicted by the two main characters in the novel, Shazral and Minah.

The unusual relationship is first depicted via the performance of premarital sex between Shazral and Minah. In most general views, all religions and cultures prohibit premarital sex. Such action is frowned upon and deemed immoral and blasphemous. For example, in traditional Filipino beliefs, communion between a man and woman should not occur until the night of their marriage and giving away one's virginity when unmarried is "immoral" (Ramones, 2011). Whereas in Christian preaching, marriage is sacred and consummation between a man and woman should not take place before they tie the knot, and the same goes for Buddhism in Ancient India, where men would not have unlawful sexual intercourse (Walshe, 1986). Premarital sex is forbidden in both Christianity and Islamic teachings (Khalife, 2014). It should be noted that most cultures and religions forbid premarital sex. This act of defiance displays the appalling and unsightly nature of a grotesque action.

Next, as pointed out earlier, the act of deviance is also depicted through Shazral and Minah, as the two have different identities. Shazral is a normal human being while Minah, on the other hand, is a dark demon that materializes as a beautiful woman around Shazral. The relationship between the two displays a traditional gothic romance between a human and a supernatural entity. However, in spite of the romantic ideology, the relationship between Shazral and Minah is nothing sweet, as Minah has approached Shazral with an ulterior motive under her belt: to kill Shazral and seize his inheritance for good. Horrendous as it sounds, the union between a human and a demon is grotesque by default. The abnormal 'rebellious' and deviant relationship portrayed by Shazral and Minah raises the need to connect it to the concept of the grotesque.

The romance portrayed by Shazral and Minah is deemed as grotesque as it breaks the cultural border. Perhaps, if their background is different, such romance would not be seen as grotesque. This is due to the nature of grotesque as Harpham put "[i]t is up to the culture to provide the conventions and assumptions that determine its [grotesque] particular form" (1982, p. xx). Cornell University Library's Division of Rare and Manuscript Collections delineates 'the grotesque' as a subject that combines "ugliness and ornament, the bizarre and the ridiculous, the excessive and the unreal" (2000). Baldick formulates grotesque as the bizarre anddistorted charactersmarked by exaggeration or abnormal human features (1990. p.93). Other than that, grotesque in the literature witnesses the celebration of the "confused and excessive" (Connelly, 2003). To further refine the notion of grotesque in literature, James Schevill describes that common impressions of the grotesque are "distorted, fantastic, ugly", and that grotesque is "essentially something we distrust, the hidden demonic fantasy that still torments and attracts us, the shadow we repress because we don't want to confront this central problem in our society" (1977). Therefore, for this research, we highlight the notions of 'demonic fantasy', 'the excessive and the unreal' and 'the horrifying and the attractive' as the building blocks of the entire study. Using the duality of theaforesaid sub-concepts as the core signifying the bigger picture of the grotesque concept, we will underline how premarital sex and a romance between a human and a demon are reasoned to be sexually deviant and ultimately grotesque.

\section{Grotesque: The Extreme And The Disturbing}

In generic designations, grotesque is summed up as a concept emphasizing the ugly, distorted and fantastic. In the conventions of literature, grotesque has become a major aesthetical mode. It is a stylistic disparity combining beauty and terror (Schevill, 1977). Over the decades, the grotesque has become rooted in the literature through the emphasis on the supernatural and the fantastic (i.e. Poe's The Cask of Amontillado, 1846; Stoker's Dracula, 1897), a monstrosity (i.e. Shelley's Frankenstein, 1818; Hugo's The Hunchback of Notre Dame, 1831), madness (i.e. Poe's The Fall of the 
House of Usher, 1839), bizarre circumstances (i.e. Carroll's Alice's Adventure in Wonderland, 1865), ghosts (Dickens's A Christmas Carol, 1843) and many more. Although, from one situation to another, grotesque has various definitions, these are not mutually exclusive, and "their range of expression runs from the wondrous to the monstrous to the ridiculous" (Connelly, 2003). The universality and wide horizons of grotesque are described by Connelly as follows:

Grotesque also describes the aberration from ideal form or from accepted convention, to create the misshapen, ugly, exaggerated, or even formless. This type runs the gamut from the deliberate exaggerations of caricature, to the unintended aberrations, accidents, and failures of the everyday world represented in realist imagery, to the dissolution of bodies, forms, and categories. (2003, p.2)

The notion of grotesque is not limited to a particular genre or topic, it is applicable to various other genres as long as the concepts of distortion, beauty and ugly, horror and comic, and abnormal are within and at the opposite ends of each scale. Hence, we would conclude that grotesque is extreme and disturbing.

As a result, the description and expression of excessive love and violent or unusual sexual behaviour are often linked to the grotesque. For example, the portrayals of love in most of Toni Morrison's works are extreme to the point of grotesque. Baker (2009) explains that the grotesque is depicted through the motifs of love and violence in Toni Morrison's novels (The Bluest Eye,1970; Song of Solomon, 1977; Tar Baby, 1981; Beloved, 1987), namely the excessive motherlove, obsessive romantic love and perverse love. Morrison's depiction of love is always interwoven with violence that corresponds to the concept of grotesque.

In Morrison's novels, characters often do things in the name of love, for love, or because of love that garner feelings and/or actions that are frequently illogical and violent. Sometimes the illogical nature of events, feelings, and actions provoke comical responses from readers... Thus, Morrison accomplishes Ruskin's definition of the grotesque in that violent events are paradoxical, invoking revulsion, amusement and amazement. (Baker, 2009, p.57)

Obsessive love, for instance, ascertains the value of extremity and displays the orthodox sense of being bizarre, "but also in the more formal sense of being simultaneously funny and horrific or strange" (Baker, 2009, p.68). Apart from obsessive love, perverse love is also a type of grotesque in relation to the topics of love. Baker states that perverse love includes strange types of 'love', like incest and paedophilia, and therefore can be seen as "fitting the colloquial understanding of the grotesque", as the 'deplorable' $(2009$, p.84). The connection between love and violence tallies with the notion of grotesque, as "the emotions involved with being in love and loving someone are complex, often contradictory, and can fluctuate and vary in intensity and thus provide ripe possibilities of grotesqueries" (Baker, 2009, p.92).

While the motifs of love and violence are the grounding subject of grotesque in Toni Morrison's novels, Ian McEwan's works' representation of grotesque materializes through the subject of deviant sexuality. The grotesque is portrayed via a "transgressive partnership and deviant sexuality" (Nahid Shahbazi and Arbaayah Ali Tarmizi, 2013, p.131). Nahid Shahbazi and Arbaayah Ali Tarmizi propose that the portrayal of deviant sexuality with regard to the grotesque is relayed in McEwan's works through an "excessive, exaggerated and violated anti-world of sexual partnership to highlight the reality of human failure in forming both emotional and physical relationship" (2013, p.140). As aforementioned, the concept of grotesque can be delivered through several components, such as ghostly figure, supernatural entity, madness and others. In the case of Ian McEwan's short stories, they celebrate the occurrence of grotesque in a more intense manner than a normal depiction of grotesqueries, as they are displayed through a fundamental use of the grotesque via the "context of deviant sexuality" (Nahid Shahbazi and Arbaayah Ali Tarmizi, 2013, p.133). Their research indicates that deviance is delivered through the portrayal of a relationship that opposes normal ones, "a subculture of failed partnership and female oppression" (Nahid Shahbazi and Arbaayah Ali Tarmizi, 2013, p.133). To conclude their findings, McEwan's short stories are heavily controlled by the ideas of "sadism, sexual molestation, perversion, masochism and sexual dissatisfaction” (Nahid Shahbazi and Arbaayah Ali Tarmizi, 2013, p.134).

In contrast to the study of grotesque, love and sexuality in Western texts, the study of grotesque with the topics of love and sexuality in the Asian context is a relatively unexplored area. In an article entitled "Where Meaning Collapses: Tunku Halim's Dark Demon Rising as Global Gothic" by Glennis Byron, she highlights several ideas that contribute to the Gothic-ness of the novel. Intentionally or not, she pinpoints how the grotesque value of Shazral and Minah. Shazral, as described, has been self-absorbed and is selfish, as his "self-interest is put above communal values and the ilmu fails to work: another friend, Affendi, wins the race and the disruption of local values and beliefs accelerates" (Byron, 2008, p.37). This particular event is befitting as the concept lies within American grotesque,since Shazral displays the epitome of "the goal of individual, materialistic success" (Schevill, 1977, p.231). The immorality of self-interest befits the concept of American grotesque - the spiritually crippled. On the other hand, Minah is also depicted as spiritually grotesque. As Byron (2008, p.38) puts it, Minah is the perfect end product of globalization, cooed as "one hell of a girl" (Halim, 1997, p. 180). To sum up,the "deception, greed and spiritual emptiness that are associated with the city are most notably embodied in Minah" (Byron, 2008, p.38). Minah portrays the coexistence of attractiveness and meaninglessness, and the concept of grotesque lies within the duality of positive-negative and beauty-ugly features.

Where Western texts have connected the grotesque with love and sexuality, Asian texts have not taken up such research. Therefore, this gap allows us to venture into this challenge of examining the portrayal of love and sexuality 
and the practice of deviant sexuality with regard to the study of the grotesque. Based on selected past studies, we find it is to sum up that, with regard to the relationship between grotesque, love and sexuality, the manifestation of grotesque is pushed to extreme ends. Therefore, concerning love and sexuality in literature, grotesque is extreme and the disturbing.

\section{The Demonic Fantasy}

Towards building a definition of the grotesque, the value of 'abnormality' comes in handy. Philip Thompson in the book The Grotesque (1972) highlights that the definition of grotesque can be further enriched with the "quality of abnormality or unnaturalness" (p. 24).

It should be clear that the reaction outlined above as the classic reaction to the grotesque - the experience of amusement and disgust, laughter and horror, mirth and revulsion, simultaneously, is partly at least a reaction to the highly abnormal. For the abnormal may be funny (this is accurately reflected in the every-day usage of 'funny' to mean both 'amusing' and 'strange') and on the other hand it may be fearsome or disgusting. (Thompson, 1972, p. 24)

In this first section of analysis, we would like to take the hint about the abnormality of the values that attract and repel us, what Schevill calls "the demonic fantasy" (1977, p.229). In our understanding, the 'demonic fantasy' is uncharacteristic by default. The make-believe of malicious elements as beautiful or attractive is grotesque as the duality displayed has contrasting values. The 'demonic fantasy' is first made known to the reader of Dark Demon Rising(hence forth Demon) when Shazral realizes that Minah is an evil dark demon, instead of a beautiful and lovely city girl.

The notion of 'demonic fantasy' as introduced in the research objectives is the manifestation of grotesque through deviant sexuality. There are two types of deviant sexuality denoted, namely: 1) premarital sex, and 2) intercourse between a human and a supernatural entity. However, for 'demonic fantasy', the deviant sexuality is revealed through the latter act. The intercourse between a human and a supernatural entity is gruesome and abnormal enough, let alone intercourse with a vicious dark demon. Although, initially, Shazral is oblivious to the gory truth, Shazral is very enticed by the loveliness of Minah, his fiancée. After the discovery, Shazral cannot help but recall the beauty and attractiveness of his former lover, but when the reality snaps him out of his idle daydream, Shazral's immediate reaction is anger and he becomes nauseated. Consider the following excerpt:

Our words continued through the night, our lips eventually meeting, our bodies falling to the rough Persian carpet of intricate design... She laughed and pushed me on the soft bed. What did I do? I laughed. And took my shirt off. And we embraced ... my breath upon hers ... her hands upon me ... my mouth ... The damn memories!! A wave of nausea hit me. Minah had never left me! She was still here, in my blood, in my loins - I hated the thought of it... The sordid feelings, the awful pleasure made me want to retch. (Demon, 1997, p. 192)

The excerpt above displays sexual intercourse between a man and a seductive demon from the point of view of Shazral. The grotesqueries are made clear with the responses elucidated by Shazral. The effect of grotesque on the narration of the deviant sexuality of a man and a demon is once again brought to light when, in his encounter with the demon Minah, Shazral is forced to recall the sexual intercourse the two had previously. When Shazral retches in horror and disgust, Minah, on the other side, displays enjoyment in mocking and finds glee in Shazral's disgust.

Yes, all a clever trick, but Minah and I are one, we are the same, you loved Minah, you loved me. When you kissed her warm full lips, you were kissing mine! When you made love to her, you were having sex with me!!” It sniggered, its lips curled to a triumphant grin. (Demon, 1997, p. 211)

The strange attractiveness of Minah as a woman and the disgusting and horrifying nature of Minah as a demon coexist, and are thus befitting of the notion of 'demonic fantasy' that attracts and repulses audiences at the same time. The sexually deviant nature of sexual intercourse between a human and a demon is successful in signifying the grotesque concept, specifically with regard to the idea of grotesque romance. The romance depicted through the act of deviant sexuality is, without doubt, grotesque in nature.

\section{The Excessive And The Unreal}

Moving on, we will illustrate the occurrence of another type of deviant sexuality, which was not mentioned in the previous section - premarital sex. As the subtitle suggests, under the heading of premarital sex, the notion of grotesque as excessive and unreal is applied throughout this section. Perhaps secularism has condoned the moral values preached by various cultures and religious beliefs around the world. However, that does not mean that such an act has become acceptable and normal. In Demon, in many scenes, Shazral signals that he is in Malay society, in a Muslim community. However, perhaps it is due to 'globalization' that he has been transformed and driven him away from the moral codes of conduct set by his culture and religion. Readers are made aware that Shazral and Minah have done a few intimate things and eventually had sexual intercourse, which is obviously frowned upon in Malay culture and forbidden by Islamic teaching.

This act can be seen as rebellious and blasphemous and counter to moral conduct and religious faith. The effect of this performance can be attested to as 'wonderful' and full of pleasure for the characters, but from the point of view of the reader, the breaking of the religious code induces mocking smirks and sparks of disgust and anger - the proposed effect of the grotesque. Although Shazral and Minah already have plans for marriage, that does not qualify them to have 
premarital intercourse or make other intimate gestures like kissing in close proximity to Minah's house. The enjoyment of committing forbidden sexual acts before marriage can be seen as unholy acts that flaunt their sexual gratification, and thus their strange satisfaction is sexually deviant in this context.

At the beginning, it is narrated in the novel that Shazral and Minah enjoy being in each other's company and their meetings always involve physical contact. In one scene, after a party in Ziggy's Zag, Shazral drives Minah to her house; and when they arrive, Minah invites Shazral in. As Minah lives alone, Shazral should not enter the house as such an action will inevitably lead to slander and temptation. Such a flirtatious invitation should have been denied by Shazral if he was aware of and still respected the teaching and moral conduct of his religion and culture. Instead, Shazral is blinded by the seductive nature of Minah and gladly chimes in with her and ignores the reality.

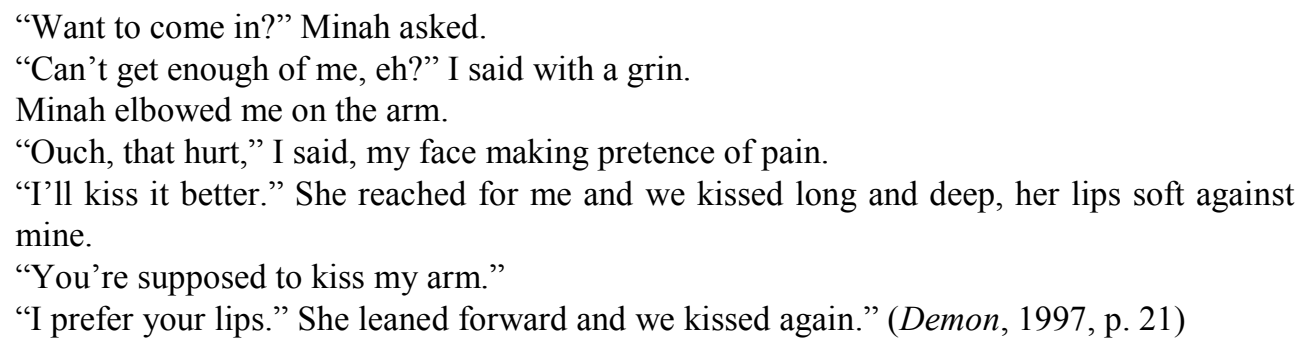

The excerpt above demonstrates the obvious seductive tone of Minah. Her playful nature lured Shazral into succumbing to the prohibited act of intimacy and physical contact. These acts of intimacy and physical contact are prohibited by Islamic teaching, let alone premarital sex.

Hence, we infer that the act of deviance depicted by Shazral and Minah is deliberate, and thus excessive. When there is no need for the kisses and, what is more, premarital sex, the sexual intercourse between the two is simply an act of deviant sexuality, a way for the two to reach sexual gratification. The delight in their pleasure despite the forbidding constraint serves as a way to manifest their romance, earning the title 'grotesque romance'.

When the other part of grotesquery is displayed, the romance between Shazral and Minah is unreal. In another phase of the story, Shazral is ready to inherit the good spirit and is taken by a mysterious force to a mystical island. To Shazral's delight, he finds Minah will be on the island with him. Mistakenly, Shazral thinks Minah is there to be his supporter, a companion for him as he kisses Minah "briefly on the lips" (Demon, 1997, p. 138). However, it is revealed later that Minah is the dark demon that has been haunting Shazral since he was younger, and she has been plotting to murder him since the beginning. Once discovered, Minahs turns into her demonic and malicious self, "her eyes venomous and I thought I saw a flesh of red" (Demon, 1997, p. 143). After Shazral manages to escape and leave the mystical island, he realizes, after all this while, that it was "Minah's satanic seduction" (Demon, 1997, p. 148). The examples here illustrate the denotation of the 'unreal' and refer back to the first subsection of analysis on demonic fantasy. The unreal existence of the human Minah has turned the romance between Shazral and Minah into a grotesque one. Although the fact that Minah is 'suddenly' no longer a human can be seen as funny, on a further note, realizing that Shazral has been professing and expressing his love to an unknown dark entity induces stark horror in the reader. Again, as the demonic fantasy, the 'unreal' is also a component of grotesque that has been channelled through deviant sexuality. Sexual intercourse and intimate contact between a human and a demon are undoubtedly strange and disturbing. The effect of such a romance befits the conventional functions and purposes of grotesque in literature. The grotesque seeks to "bewilder and disorient, to bring [the] reader up short, jolt him out of accustomed ways of perceiving the world and confront him with a radically different, disturbing perspective" (Thompson, 1972, p. 58). As a result, deviant sexuality is grotesque in such a way that the romance is excessive and unreal.

\section{The Horrifying and The Attractive}

Extending the two components of grotesque contributing to the grotesque romance previously discussed, this subsection will specifically underline the grotesque as horrifying and the attractive. In the book entitled Modern Art and The Grotesque, Frances. S. Connelly describes the grotesque by what it does to "boundaries, transgressing, merging, overflowing, destabilizing them," or in other words, grotesque is a "boundary creature" and ceases to exist unless it is subjected to such relations. Manipulating this boundary and transgression concept, we argue that the romance between Shazral and Minah is a merger between the horrifying and the attractive. The merged value has made their romance grotesque, and as the two previous subsections describe, grotesque romance is represented through deviant sexuality.

We mentioned earlier the scene where Shazral was taken to a mystical island to complete the ritual of accepting the family's inheritance of the good spirit of hantu pusaka. In his anxiety and adrenalin rush, he never expects Minah to be on the same island. However, perhaps it is because of his love for her, but Shazral feels strangely relieved to see Minah on the island with.

Her long hair was billowing beautifully in the wind - a dancing wave of celebration - her smile warm and welcoming as if it was our wedding day... Within an instant, before she could utter a word, I had reached her pulling her body into my arms, her soft breasts against my chest... my entire self breathing in her musky, giddy fragrance. (Demon, 1997, p. 136) 
In the midst of the confusion, Shazral is noticeably seeking comfort and delight in Minah's physical attractiveness. Attractiveness is overflowing from Minah, as described in the above excerpt. In the whole nerve-wrecking situation of waiting to accept his inheritance, the manner displayed by Shazral seems odd and, in extreme words, the whole picture is oddly intimate and erotic. It appears to be a very strange choice of time for Minah to appear "warm and welcoming" and as if she is waiting for him "on their wedding day", when the waiting situation is hardly a celebratory event. There is attractiveness in the eyes of Shazral, but the effect of the horror lies within the reader's perception. Minah, as we are already know, is the dark demon waiting to kill Shazral and take his inheritance. Knowing that Shazral has found comfort in her human form's attractiveness, Minah manipulates the knowledge and puts it to maximum use. She appears as the lovely and pretty Minah and has taken to seducing and convincing Shazral to kill his own good spirit instead of killing the bad demon (which is Minah herself).

This undeniable physical attractiveness that binds the two portrays the kind of romance based on physicality and sexual appeal, a deviation from the notion of true or Platonic love. This manipulation can be seen as what Thompson outlines as the kind of grotesque found in the works of Jean Paul - the tradition of "satanic and black humour" (1972). Looking from the point of view of Minah, her plotting is very deceitful and cunning. In her demonic form, she materializes as the lovely Minah and makes Shazral forget his anxiety and purpose by inviting him to kiss her in the middle of the chaotic situation. The use of this sensual gesture is no other than a means to deceive and distract Shazral from receiving and protecting his one and only family inheritance that Minah has been longing to kill and destroy for decades. The act of kissing and physical pleasure as a distraction elucidates both types of deviant sexuality that we proposed earlier. The manifestation of deviant sexuality is subtle but still conveys the notion of grotesque romance. Here, grotesque romance is not manifested through the whole action, but more as the psychological effect of grotesque. When Shazral finds it amusing and delightful to be kissing and intimate with Minah, the reader is forced at first to empathize with Shazral, but gradually barbaric delight is turned into disgust. It is first comical and then cynical as the reader finds that Shazral is after all very much into physical attractiveness and sensuality, but the role of the comic in the grotesque has developed into a tension.

Despite Shazral's initial perceptions of Minah's presence and attractiveness, Shazral later comes to know that Minah is the dark demon that he should have killed and destroyed in the first place. He also realizes that Minah is a form of deception that has materialized in order to blind his eyes, a form of attractiveness used to distract him from his purpose. And from this point on, Minah has become a subject of horror for him. Nevertheless, Minah still appears as the naturally seductive and lovely Shazral to mock him. Shazral admits that he has been visionless in the embrace of Minah. "But Minah did not exist. It had woven a spell of love, an evil spell, evil, pure and simple. I abruptly pushed opened the window in retaliation of her memory..." (Demon, 1997, p. 149). As much as Minah is the figure representing the attractive and the horrifyingly physical, the romance between them - or at least the memory of it - has also turned into the attractive and the horrifying.

Furthermore, at a later stage, Shazral has become fully aware of Minah's trickery. Minah, in her sultry mode can be seen as actively suggestive in that manner. From this perspective, Minah is 'active' like the female protagonist in Angela Carter's Heroes and Villains, Marianne. Zirange in her analysis postulates that Marianne is unconventional, as she is "the one who is aggressive and takes initiative in the action [romantic gestures]" (2013, p. 92). As he put the pieces of the puzzle together, he becomes aware that the sensuality of Minah is a way to lure him and entice him into sexual activities:

I could have used the ilmu to destroy the hantu jahat. I'd been to the house yet came away empty-handed. It lay empty, but for the painting on the wall. A message for me. Some kind of warning, mixed with its dark humour. Kiss me. I had kissed Minah, our lips caressing. She was an invention, made up by the hantu jahat, to gain my confidence. To pull me to that house, where it could wave its evil and brought an all-consuming blindness to my eyes. As far as I was concerned, she was dead. And so was the man who kissed her. (Demon, 1997, p. 179)

Shazral's musing and monologue clearly display the grotesque that has taken hold of him. The grotesque romance and all the pretence in the name of love, the manifestations of deviant sexuality, have devastated Shazral into disbelief and urged him to feel nauseous every time the memory of their kisses and sexual intercourses comes into his mind. In relation to study of the grotesque, Ewa Kuryluk stresses the application of the approach in the manner of the "erotic and heretic" (qtd. in Shahbazi and Tarmizi, 2013). And thus, up to this point, the grotesque romance in Dark Demon Rising has been conveyed via deviant sexuality - a subject much related to the nuance of the erotic.

\section{Conclusion}

Therefore, it can be concluded that, in the novel Dark Demon Rising (1997), the functions and purposes of grotesque are delivered through the occurrences of strange romance and the narration of deviant sexuality. The theme of love or romance is manifested through the deviant sexuality of the protagonist Shazral and his fiancée Minah. The romance is deemed to be sexually deviant as the couple portray the 'rebellious' nature of breaking the moral code conduct and religious teaching as they commit intimate and sensual gestures and eventually have sexual intercourse. The idea of going against morality is unholy and disturbingly immoral, thus their persistence to engage in premarital intercourse is seen as having the grotesque effect of 'demonic fantasy', signifying the notion of a grotesque romance. Apart from that, the communion between a human and a demon is also an example of sexual deviance. On top of having premarital sex, Shazral and Minah have committed the unthinkable of sexual intercourse between two different entities. 
The romance is grotesque as it portrays the excessive and unreal romance of a human and a demon. And thirdly, the deviant sexuality of premarital sex and intercourse between human and demon is utterly grotesque as romance is the epitome of the notion of grotesque as attractive and horrifying. The deceiving beauty and temporary sexual gratification are no other than a way to manifest and glorify grotesque romance in a novel, as displayed by Shazral and Minah. As the grotesque in general includes the elements of bizarre, strangeness, exaggeration and intense emotions, the portrayal of grotesque romance in Dark Demon Rising tallies with the very essence of the grotesque in general, and the effect of grotesque is both shocking and psychologically impactful. From here, we draw out three components that are proportionate in contributing to grotesque romance: 1) demonic fantasy, 2) the excessive and the unreal, and 3) the horrifying and the attractive. And two components of grotesque successfully demonstrated by the act of deviant sexuality: - 1) premarital sex, and 2) sexual intercourse between a human and a supernatural entity.

\section{References}

Ali, H. M. (2013). The Abject Lover of the Courtly Love Era. 3L: The Southeast Asian Journal of English Language Studies, 19 (3), 11-19.

Baker, A. R. (2009). The Presence, Roles and Functions of the Grotesque in Toni Morrison's Novels. Indiana University of Pennsylvania.

Baldick, Ch. (1990). Concise Dictionary of Literary Terms. Oxford: Oxford University Press

Byron, G. (2008). Where Meaning Collapses: Tunku Halim's Dark Demon Rising as Global Gothic. Ng, Andrew Hock Soon. Asian Gothic: Essays on Literature, Film and Anime . North Carolina: McFarland \& Company, Inc., Publishers, 32-45.

Connelly, F. S. (2003). Modern Art and the Grotesque. Cambridge: Cambridge University Press

Halim, T. (1997). Dark Demon Rising. Petaling Jaya: Pelanduk Publications (M) Sdn Bhd

Harpham, G. G. (1982). On the Grotesque. New Jersey: Princeton University Press

Khalife, M. Why Pure Religions Forbid Premarital Sex? February 2014. http://www.onislam.net/english/ask-aboutislam/ethics-and-values/muslim-character/469183-why-pure-religions-forbid-premarital-sex.html.

Shahbazi Moghadam, N. and Arbaayah A. T. (2013). Grotesque Representations of Deviant Sexuality in Ian McEwan's Selected Short Stories. Pertanika Journal of Social Sciences and Humanities, 21(S),131-142.

“Oxford Dictionaries.” Oxford: Oxford University Press, 2014.

Ramones, R. A. Premarital Sex and Some Odd Filipino Traditional Beliefs. 24 September 2011. $<$ http://r03249.wordpress.com/2011/09/24/premarital-sex-and-some-odd-filipino-traditional-beliefs/>.

Schevill, J. (1977). Notes of the Grotesque: Anderson, Brecht, and Williams. Twentieth Century Literature, 23(2), 229238.

--- (2000). The Grotesque. The Fantastic in Art and Literature. Cornell Institute for Digital Collections.

Thompson, Ph. (1972).The Grotesque. London: Methuen \& Co Ltd

Walshe, M. O'C. (1986). Buddhism and Sex. Sri Lanka: Buddhist Publication Society

Zirange, R. S. (2013). “Angela Carter's Heroes and Villains: A Dystopian Romance . 3L: The Southeast Asian Journal of English Language Studies, 19(2), 89-98. 